\title{
Existing trends of trimming for apparels
}

Sarita Devi, Vivek Singh, Parveen Punia and Nisha Arya

Received: 07.12.2017; Revised: 11.04.2018; Accepted: 01.05.2018

See end of the paper for authors' affiliations

\section{Sarita Devi}

Department of Textile and

Apparel Designing, I.C. College

of Home Science, C.C.S. Haryana

Agricultural University, Hisar

(Haryana) India
ABSTRACT : Trimmings are an ornamental addition used on clothing and home furnishing such as facing, piping, braids, cords, laces, tassels patches, borders etc. Market is flooded with trimmings of numerous sizes, shapes, styles and colours. The study was conducted to know the latest trends of trimmings. Ten shopkeepers purposively selected ten shops and thirty consumers visiting these shops were selected on the basis of responsively to collect information regarding existing trends of trimmings. The information regarding availability of trimmings and sale of trimmings was collected through shopkeepers. Thirty consumers visiting these trimming shops were selected as respondents to know their usage pattern of trimmings for apparels. The information was collected using self-structured interview schedule and by observations. Majority of respondents preferred surface embellishments for female wears followed by children and male wears. The ornamentation materials (beads, sequins, rhinestone etc.) and readymade decorative trimmings were the most preferred types of surface embellishments used for female apparels. Majority of consumers preferred piping and facing as functional trimmings and laces and borders as decorative trimmings for formal, casual and night female wears. Most of consumers preferred laces, borders and tassels, as decorative trimmings for female formal wears.

KEY WORDS: Trimmings, Fabric used, Embellishment materials, Apparels

- HOW TO CITE THIS PAPER : Devi, Sarita, Singh, Vivek, Punia, Parveen and Arya, Nisha (2018). Existing trends of trimming for apparels. Asian J. Home Sci., 13 (1) : 280-285, DOI: 10.15740/HAS/AJHS/ 13.1/280-285. Copyright@ 2018: Hind Agri-Horticultural Society. 